\title{
STUDY OF SHEAR WALLS IN MULTISTORIED BUILDINGS WITH DIFFERENT THICKNESS AND REINFORCEMENT PERCENTAGE FOR ALL SEISMIC ZONES IN INDIA
}

\author{
Sanjay Sengupta ${ }^{1}$ \\ ${ }^{1}$ Assistant Professor, Department of Civil Engineering, Dr. B.C. Roy Engineering College, Durgapur, West-Bengal, \\ India
}

\begin{abstract}
This paper investigates the effect of different thickness and corresponding reinforcement percentages required for shear walls on multi-storied buildings. Building models with shear walls are developed using ETABS. The location of the shear walls are kept same and a comparative study is done for different thickness of the shear wall for different height of the building $(5$ storied, 10 storied and 15 storied). In each of the cases corresponding reinforcement percentages required are found out. It is observed that for a constant thickness of shear wall, reinforcement percentage increases with increase of both seismicity and number of stories. It is also observed that for all zones, the reinforcement percentage increases if the shear wall thickness increases for a certain range of thickness and then decreases for a certain range of thickness. Thus the results indicate that increase of shear wall thickness is not always effective for earthquake resistant design.
\end{abstract}

Keywords: Shear Wall, ETABS, earthquake resistant design.

\section{INTRODUCTION}

Now a day, Shear Walls are the most common structures built inside the structures in order to counteract severe earthquake forces. Earthquake is a major concern for the engineers to give stability to the buildings. Properly designed and detailed buildings with shear walls have shown very good performance in past earthquakes. Shear walls must provide the necessary lateral strength to resist horizontal earthquake forces. When shear walls are strong enough, they will transfer these horizontal forces to the next element in the load path below them. These other components in the load path may be other shear walls, floors, foundation walls, slabs or footings.

Shear walls also provide lateral stiffness to prevent the roof or floor above from excessive side-sway. When shear walls are stiff enough, they will prevent floor and roof framing members from moving off their supports. Also, buildings that are sufficiently stiff will usually suffer less nonstructural damage.

\section{ANALYTICAL MODELLING OF THE}

\section{BUILDING}

In order to study the effect of shear wall on multi-storey buildings and the force generated in the shear walls, the building plan as shown in Figure 1. is developed in ETABS. A representative five storied model of the same is also shown in Figure 2. The asymmetric nature of the plan ensures that forces generated due to rotational movements of the floor diaphragms come into consideration. Positions of the shear walls are shown in Figure 1 as P1, P2, P3 and P4. The plan is kept same throughout so that the results obtained for different number of stories in different seismic zones of India can be compared for the same typical plan.

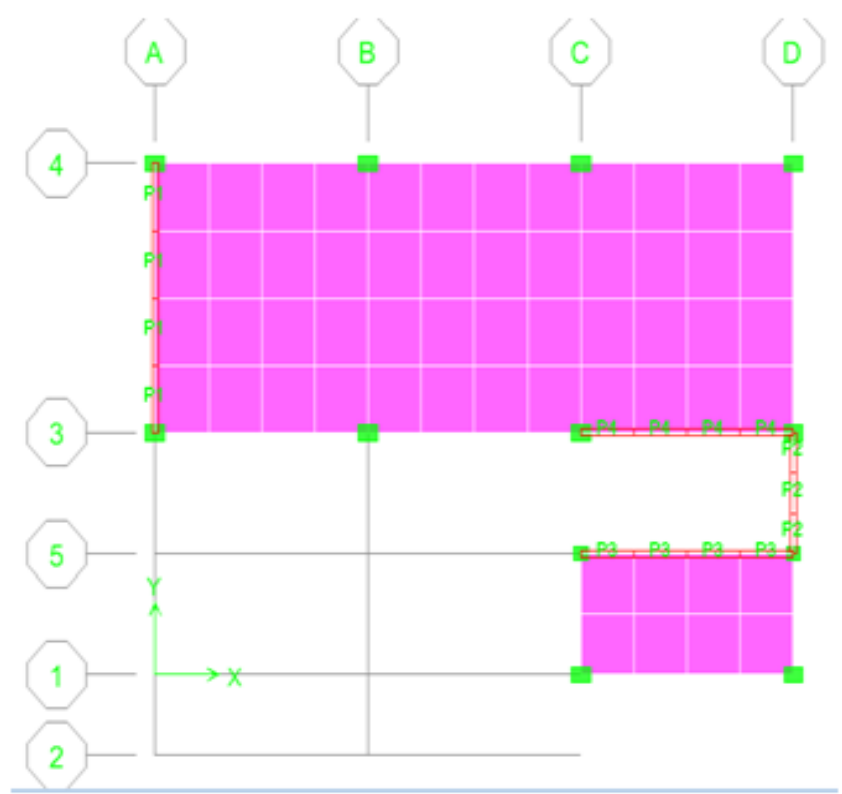

Fig-1: Plan of the building considered for analysis.

A comparison between the required percentage reinforcement of shear walls located in different position as shown in Figure 1 (two in the ' $X$ ' direction, i.e. P3 \& P4 and two in the ' $\mathrm{Y}$ ' direction i.e. P1 \& P2) is done for all the seismic zones of India (i.e. zone II, zone III, zone IV and zone V) and is shown in Table 1 and Table 2. The thicknesses of the shear walls considered for the above analysis are 5 inches, 10 inches, 15 inches and 20 inches. 


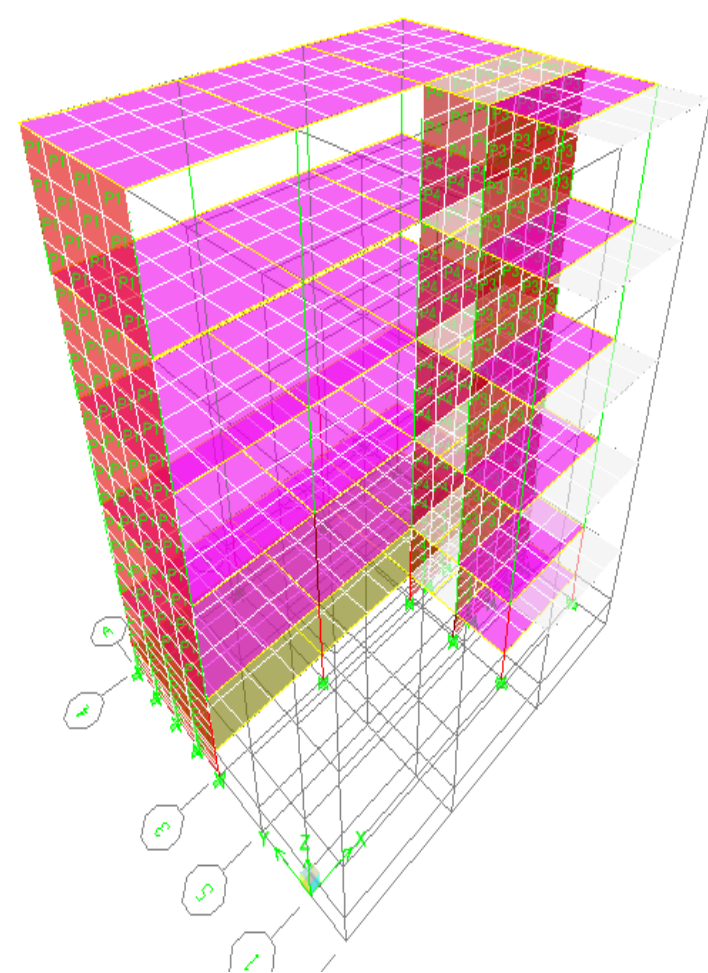

Fig-2: Three dimensional model of the five storied building developed in ETABS

The results are divided in five categories as enumerated below:

Category 1: Under this category comparison is done between the required percentage of reinforcement for various seismic zones. The thickness of the shear walls considered is $5,10,15$ and 20 inches. For each thickness, the reinforcement percentages are determined for different seismic zones for different number of stories. It is observed that reinforcement percentage increases with the increase of the severity of the seismic zone for a particular number of stories.

Category 2: In this category, thickness of all the shear walls is kept at 10 inches. The reinforcement percentage required for different number of stories is observed only for P2. It is observed that reinforcement percentage increases with respect to severity of the seismic zone.

Category 3: In this case plotting is done for the required percentage of reinforcement against different thicknesses of shear wall for a particular pier (like P1 or P2 etc.) for different seismic zone. From this plotting it is found that for a certain limit, the reinforcement percentage increases with the increase of wall thickness but after that it decreases.

Category 4: Under this category graphs show the percentage reinforcement against the storey level for different seismic zone irrespective of the position of the shear walls (like P2, P4 etc.) from which it can be said that, percentage reinforcement will not always increase with the increase in number of stories.
Category 5: In this case plotting is done between the required percentage reinforcement and the shear wall number or the position of the shear walls for the different seismic zone irrespective of the storey height.

\section{RESULTS AND DISCUSSION}

The analytical results category wise described below:

\subsection{Category 1}

From the figure 3 (a), (b) and (c) shown below it is found that for the 5 inch thick shear wall reinforcement percentage is increased from low to high severity. In case of P1, P3 and $\mathrm{P} 4$ this increment is gentle from zone II to zone IV but steep from zone IV to zone $\mathrm{V}$. In case of $\mathrm{P} 2$ a uniform increment is found.

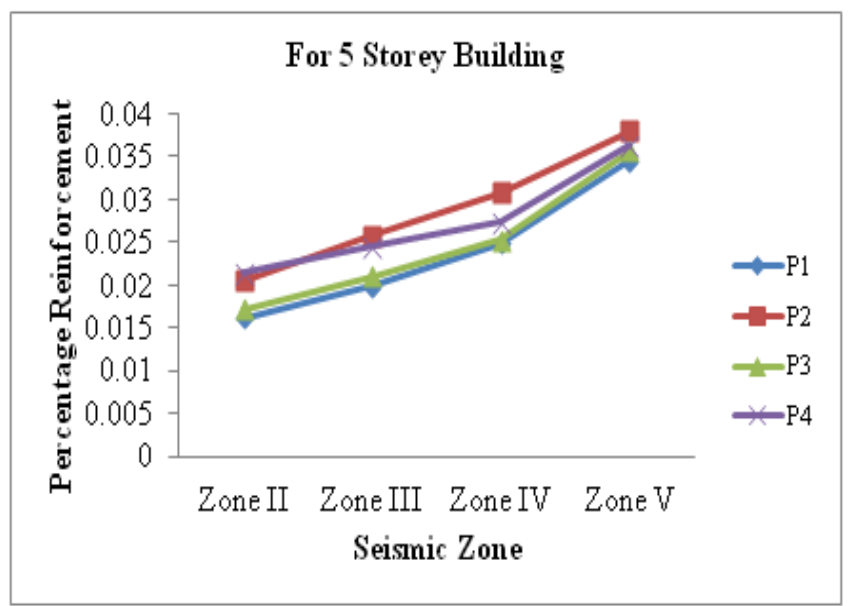

Fig- 3(a): For 5 storey building

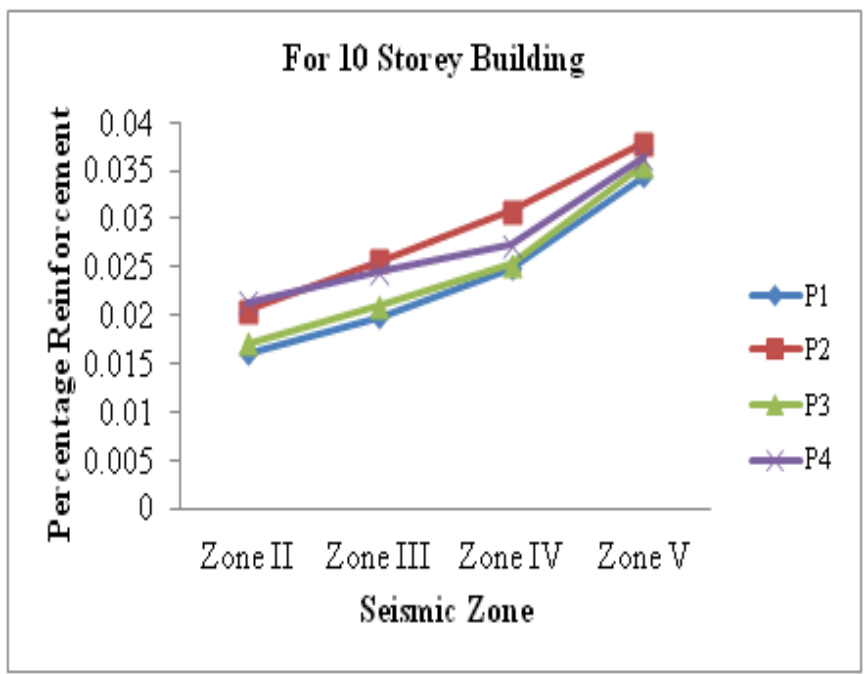

Fig-3(b): For 10 storey building

Same trend is found in case of 10 inch shear wall shown in figure 4 (a), (b) and (c), but here the steepness is less than the previous one. 
Table-1: Percentage of reinforcement required in shear walls for seismic zone II and III

\begin{tabular}{|c|c|c|c|c|c|c|c|c|}
\hline \multirow{3}{*}{$\begin{array}{l}\text { Thickness } \\
\text { of Shear } \\
\text { Wall } \\
\text { (in } \\
\text { inches) }\end{array}$} & \multirow{3}{*}{$\begin{array}{l}\text { Shear } \\
\text { Wall } \\
\text { No. }\end{array}$} & \multirow{3}{*}{$\begin{array}{l}\text { Bottom } \\
\text { Reinforcement } \\
\text { at }\end{array}$} & \multicolumn{6}{|c|}{ Shear Wall Reinforcement ( \% reqd.) } \\
\hline & & & \multicolumn{3}{|l|}{ ZONE II } & \multicolumn{3}{|l|}{ ZONE III } \\
\hline & & & $\begin{array}{l}5 \\
\text { STOREY }\end{array}$ & $\begin{array}{l}\text { 10 } \\
\text { STOREY }\end{array}$ & $\begin{array}{l}15 \\
\text { STOREY }\end{array}$ & $\begin{array}{l}5 \\
\text { STOREY }\end{array}$ & $\begin{array}{l}\text { 10 } \\
\text { STOREY }\end{array}$ & $\begin{array}{l}15 \\
\text { STOREY }\end{array}$ \\
\hline \multirow{8}{*}{$\begin{array}{l}5 \text { inches } \\
(12.7 \mathrm{~cm})\end{array}$} & \multirow{2}{*}{$\mathrm{P} 1$} & Tie Level & 0.0025 & 0.022 & 0.0161 & 0.0025 & 0.0249 & 0.0198 \\
\hline & & 5th Floor & 0.0025 & 0.0173 & 0.0075 & 0.0025 & 0.0187 & 0.0115 \\
\hline & \multirow{2}{*}{$\mathrm{P} 2$} & Tie Level & 0.0066 & 0.0256 & 0.0205 & 0.0071 & 0.0339 & 0.0257 \\
\hline & & 5th Floor & 0.0025 & 0.0185 & 0.0146 & 0.0025 & 0.0209 & 0.0184 \\
\hline & \multirow{2}{*}{ P3 } & Tie Level & 0.0059 & 0.0194 & 0.0171 & 0.0071 & 0.0222 & 0.021 \\
\hline & & 5th Floor & 0.0025 & 0.0205 & 0.0109 & 0.0025 & 0.0232 & 0.0135 \\
\hline & \multirow{2}{*}{$\mathrm{P} 4$} & Tie Level & 0.0125 & 0.0296 & 0.0214 & 0.0137 & 0.0296 & 0.0245 \\
\hline & & 5th Floor & 0.0025 & 0.0347 & 0.0115 & 0.0025 & 0.0197 & 0.0133 \\
\hline \multirow{8}{*}{$\begin{array}{l}10 \text { inches } \\
(25.4 \mathrm{~cm})\end{array}$} & \multirow{2}{*}{$\mathrm{P} 1$} & Tie Level & 0.0025 & 0.0039 & 0.0208 & 0.0025 & 0.0068 & 0.0229 \\
\hline & & 5th Floor & 0.0025 & 0.0025 & 0.0187 & 0.0025 & 0.0025 & 0.0212 \\
\hline & \multirow{2}{*}{$\mathrm{P} 2$} & Tie Level & 0.0025 & 0.0132 & 0.0272 & 0.0025 & 0.0183 & 0.0313 \\
\hline & & 5th Floor & 0.0025 & 0.0037 & 0.0148 & 0.0025 & 0.0066 & 0.0179 \\
\hline & \multirow{2}{*}{ P3 } & Tie Level & 0.0025 & 0.0083 & 0.0242 & 0.0025 & 0.0108 & 0.0271 \\
\hline & & 5th Floor & 0.0025 & 0.0056 & 0.0213 & 0.0025 & 0.0073 & 0.024 \\
\hline & \multirow{2}{*}{ P4 } & Tie Level & 0.0025 & 0.0165 & 0.0272 & 0.0035 & 0.0193 & 0.0291 \\
\hline & & 5th Floor & 0.0025 & 0.0077 & 0.0147 & 0.0025 & 0.0094 & 0.0158 \\
\hline \multirow{8}{*}{$\begin{array}{l}15 \text { inches } \\
(38.1 \mathrm{~cm})\end{array}$} & \multirow{2}{*}{ P1 } & Tie Level & 0.0025 & 0.0076 & 0.026 & 0.0025 & 0.0016 & 0.0258 \\
\hline & & 5th Floor & 0.0025 & 0.0025 & 0.0202 & 0.0025 & 0.0025 & 0.0151 \\
\hline & \multirow{2}{*}{$\mathrm{P} 2$} & Tie Level & 0.0025 & 0.0097 & 0.027 & 0.0025 & 0.014 & 0.0304 \\
\hline & & 5th Floor & 0.0025 & 0.0025 & 0.0203 & 0.0025 & 0.0025 & 0.0226 \\
\hline & \multirow{2}{*}{ P3 } & Tie Level & 0.0025 & 0.007 & 0.0214 & 0.0025 & 0.0095 & 0.0246 \\
\hline & & 5th Floor & 0.0025 & 0.0025 & 0.0208 & 0.0025 & 0.0025 & 0.0192 \\
\hline & \multirow{2}{*}{ P4 } & Tie Level & 0.0025 & 0.0141 & 0.0283 & 0.0025 & 0.0178 & 0.031 \\
\hline & & 5th Floor & 0.0025 & 0.0025 & 0.0202 & 0.0025 & 0.0025 & 0.0145 \\
\hline \multirow{8}{*}{$\begin{array}{l}20 \text { inches } \\
(50.8 \mathrm{~cm})\end{array}$} & \multirow{2}{*}{$\mathrm{P} 1$} & Tie Level & 0.0025 & 0.0036 & 0.0161 & 0.0025 & 0.0074 & 0.0198 \\
\hline & & 5th Floor & 0.0025 & 0.0025 & 0.0095 & 0.0025 & 0.0025 & 0.0115 \\
\hline & \multirow{2}{*}{ P2 } & Tie Level & 0.0025 & 0.0078 & 0.0205 & 0.0025 & 0.0131 & 0.0257 \\
\hline & & 5th Floor & 0.0025 & 0.0025 & 0.0167 & 0.0025 & 0.0025 & 0.0186 \\
\hline & \multirow{2}{*}{ P3 } & Tie Level & 0.0025 & 0.0109 & 0.0169 & 0.0025 & 0.0093 & 0.0209 \\
\hline & & 5th Floor & 0.0025 & 0.0025 & 0.0104 & 0.0025 & 0.0025 & 0.0135 \\
\hline & \multirow{2}{*}{$\mathrm{P} 4$} & Tie Level & 0.0025 & 0.0111 & 0.0212 & 0.0025 & 0.0131 & 0.0243 \\
\hline & & 5th Floor & 0.0025 & 0.0025 & 0.0114 & 0.0025 & 0.0025 & 0.0132 \\
\hline
\end{tabular}

Table-2: Percentage of reinforcement required in shear walls for seismic zone IV and V

\begin{tabular}{|c|c|c|c|c|c|c|c|c|}
\hline \multirow{3}{*}{$\begin{array}{l}\text { Thickness } \\
\text { of Shear } \\
\text { Wall } \\
\text { (in } \\
\text { inches) }\end{array}$} & \multirow{3}{*}{$\begin{array}{l}\text { Shear } \\
\text { Wall } \\
\text { No. }\end{array}$} & \multirow{3}{*}{$\begin{array}{l}\text { Bottom } \\
\text { Reinforcement } \\
\text { at }\end{array}$} & \multicolumn{6}{|c|}{ Shear Wall Reinforcement ( \% reqd.) } \\
\hline & & & \multicolumn{3}{|l|}{ ZONE IV } & \multicolumn{3}{|l|}{ ZONE V } \\
\hline & & & $\begin{array}{l}5 \\
\text { STOREY }\end{array}$ & $\begin{array}{l}\text { 10 } \\
\text { STOREY }\end{array}$ & $\begin{array}{l}15 \\
\text { STOREY }\end{array}$ & $\begin{array}{l}5 \\
\text { STOREY }\end{array}$ & $\begin{array}{l}\text { 10 } \\
\text { STOREY }\end{array}$ & $\begin{array}{l}15 \\
\text { STOREY }\end{array}$ \\
\hline \multirow{4}{*}{$\begin{array}{l}5 \text { inches } \\
(12.7 \mathrm{~cm})\end{array}$} & \multirow{2}{*}{$\mathrm{P} 1$} & Tie Level & 0.0025 & 0.0292 & 0.0249 & 0.0067 & 0.0337 & 0.0345 \\
\hline & & 5th Floor & 0.0025 & 0.0211 & 0.0154 & 0.0025 & 0.0252 & 0.0353 \\
\hline & \multirow{2}{*}{$\mathrm{P} 2$} & Tie Level & 0.0115 & 0.034 & 0.0308 & 0.0182 & 0.0375 & 0.0379 \\
\hline & & 5th Floor & 0.0025 & 0.0243 & 0.0229 & 0.0025 & 0.0283 & 0.0299 \\
\hline
\end{tabular}




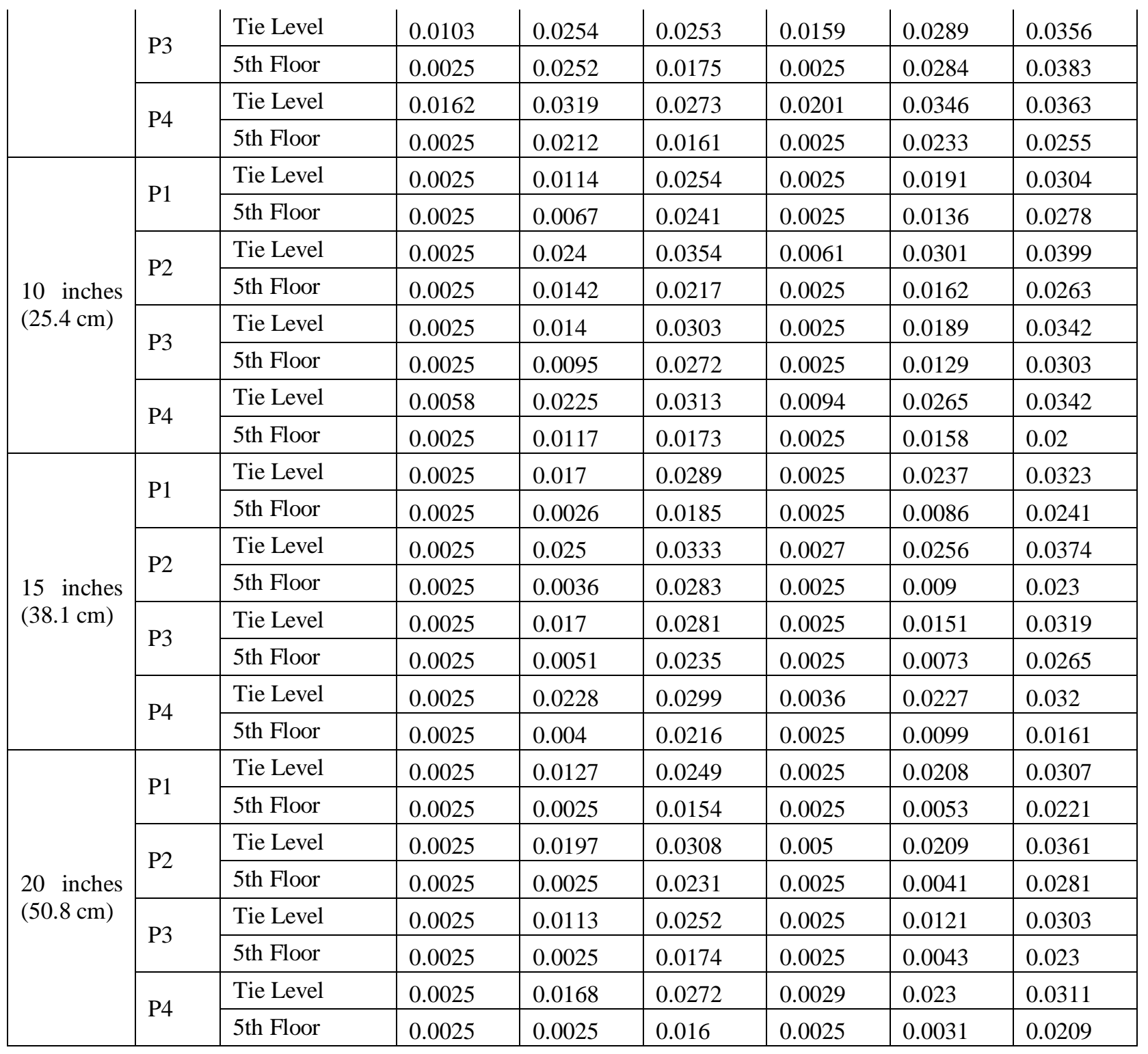

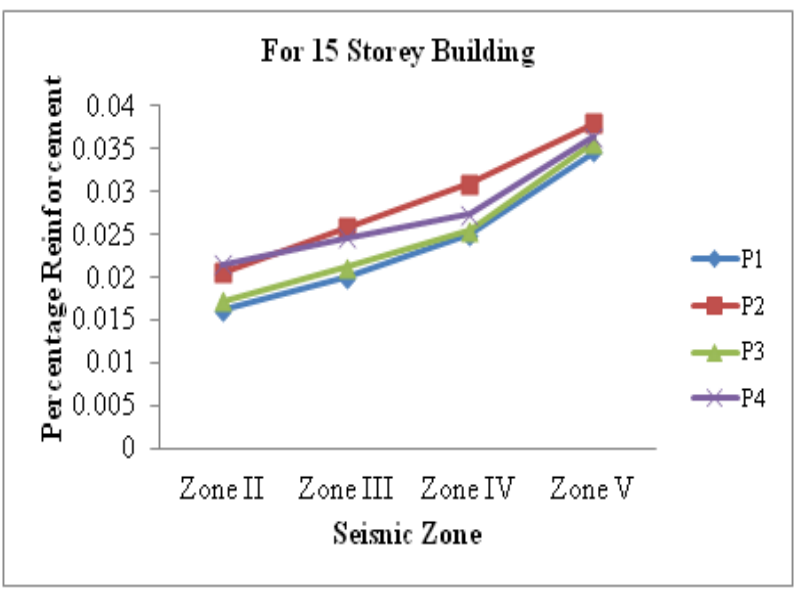

Fig- 3(c): For 15 storey building

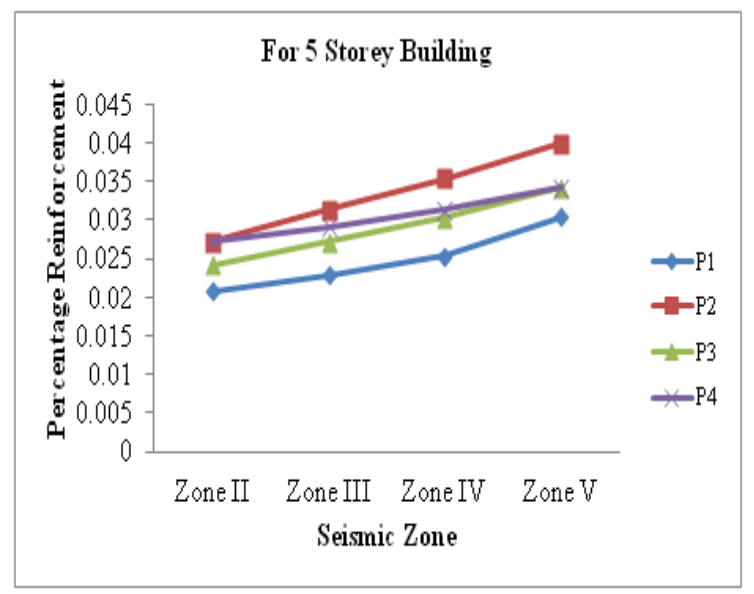

Fig-4(a) : For 5 storey building

Fig-3: Variation of Percentage Reinforcement for 5 inch thick Shear Wall for different zone 


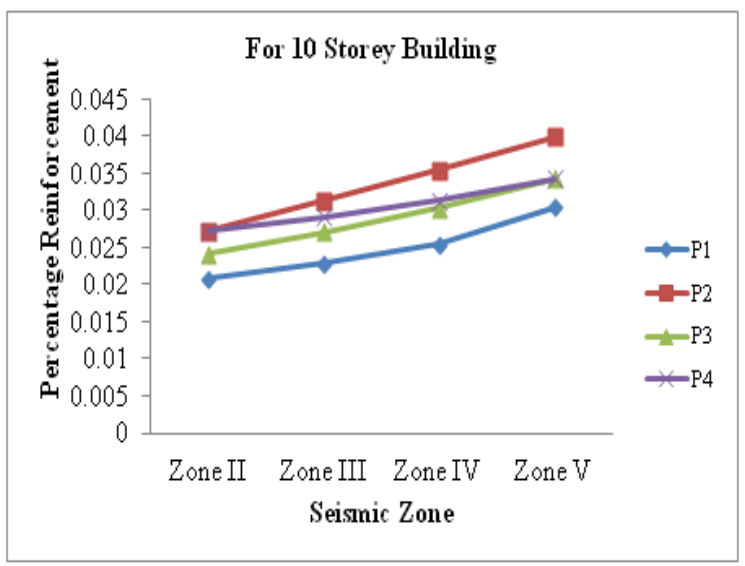

Fig-4(b): For 10 storey building

From the figure 5 (a), (b) and (c) it is predicted that in case of P2 \& P3 a uniform increment is observed from zone II to zone $\mathrm{V}$, but in case of $\mathrm{P} 1$ a sudden decrement is found from zone III to zone IV and after that it further increases. For P4 percentage reinforcement is primarily decreased from zone II to zone III, then it is increased from zone III to zone V.

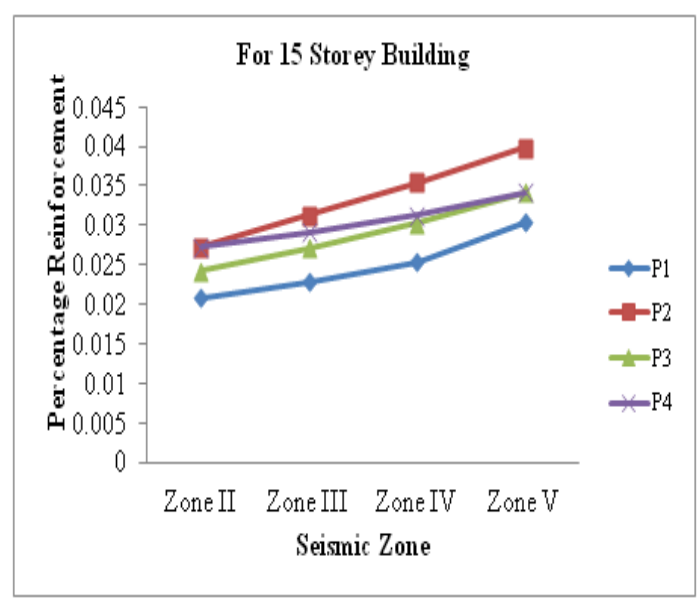

Fig-4(c): For 15 storey building

Fig-4: Percentage Reinforcement for 10 Inch thick Shear Wall for zones

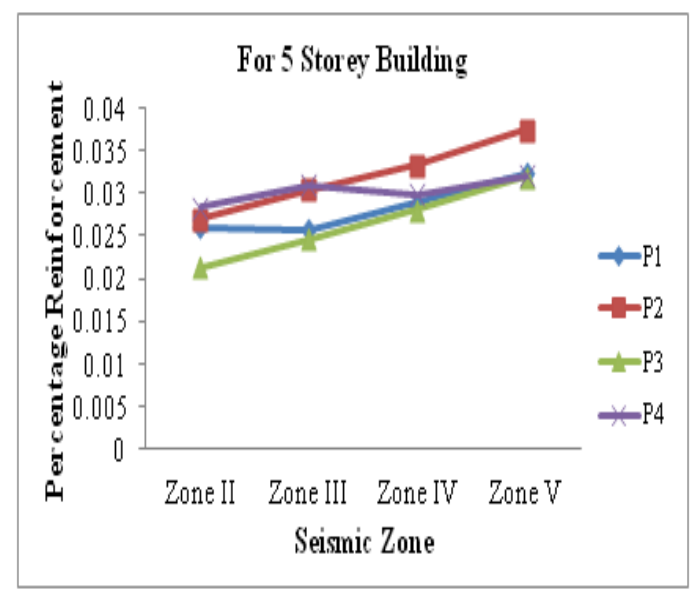

Fig-5(a): For 5 storey building

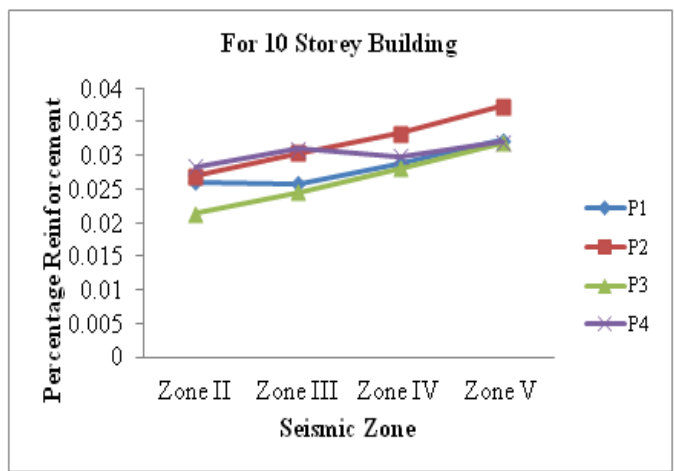

Fig-5(b): For 10 storey building

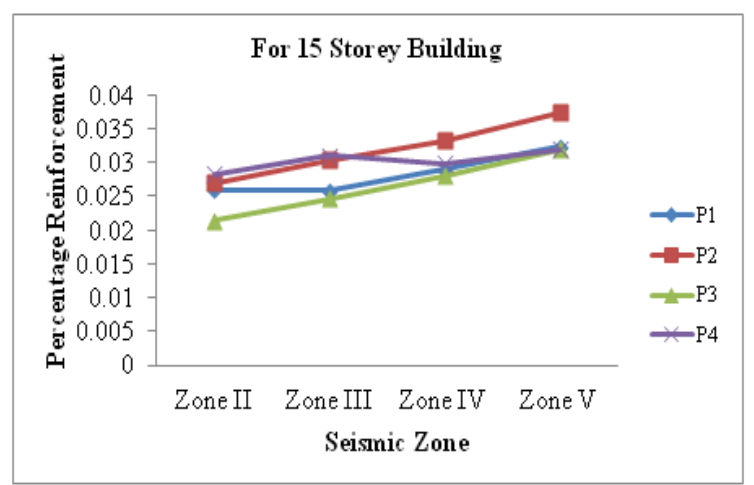

Fig-5(c): For 15 storey building

Fig-5: Percentage Reinforcement for 15 inch Thick Shear Wall of zones

The nature of the 20 inch shear wall is as same as the 10 inch shear wall as shown in the figure 6 (a), (b) and (c).

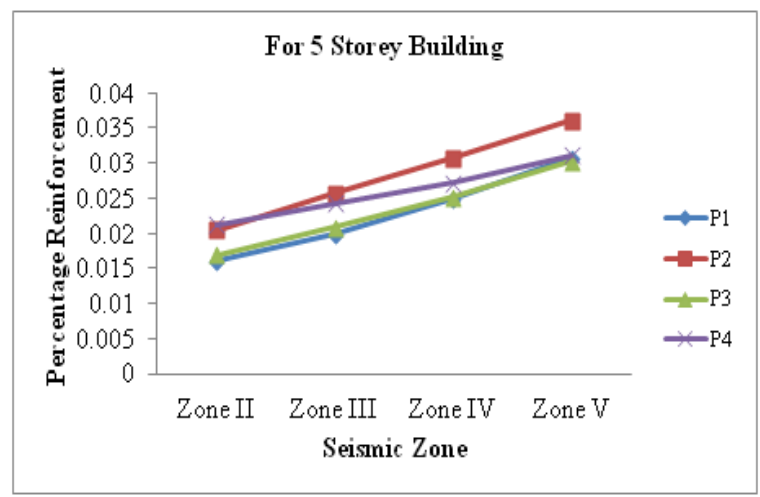

Fig-6(a): For 5 storey building

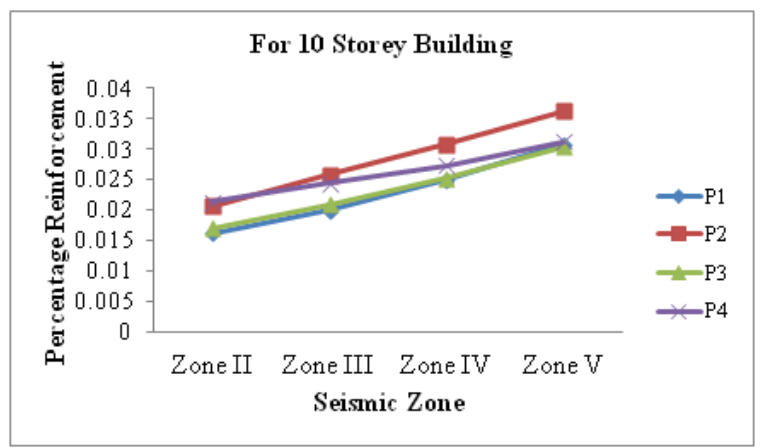

Fig- 6(b): For 10 storey building 


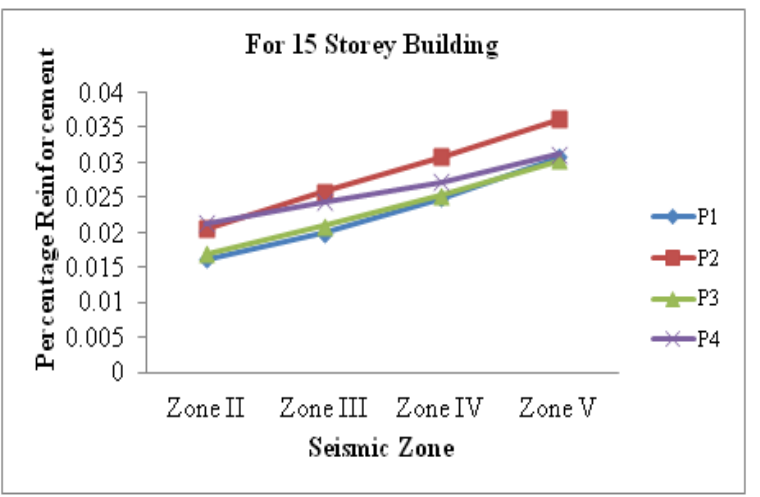

Fig-6(c): For 15 storey building

Fig-6: Percentage Reinforcement for 20 inch thick Shear Wall for different zones

\subsection{Category 2}

From the figure 7 it is being observed that for 10 inch thick P2 shear wall, percentage reinforcement is increased with the increase of seismic zone and respective storey height.

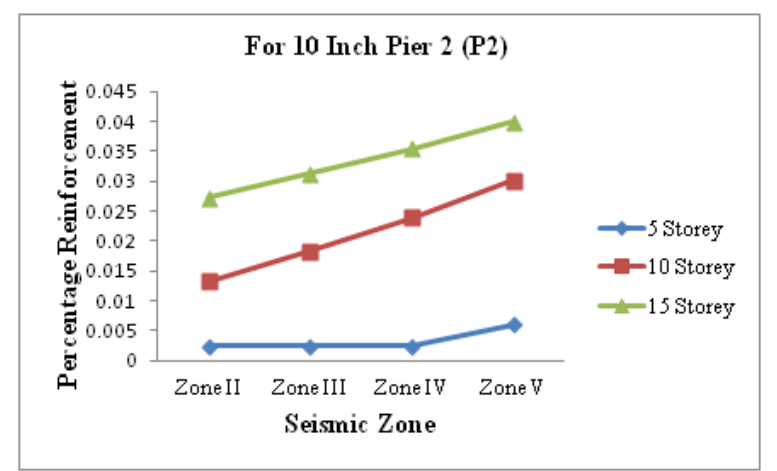

Fig-7: Percentage Reinforcement required in P2 for 10 inch thick shear walls for different number of stories

\subsection{Category 3}

From the figure 8(a) shown, it is being observed that for P1 percentage reinforcement is increased with the increase of storey thickness (from 5 inch to 15 inch) and from 15 inch to 20 inch it is decreased. This trend is found from zone II to zone IV. In case of zone $\mathrm{V}$ maximum reinforcement is required for 5 inch shear wall.

For P2 it is noticed that percentage reinforcement is increased with the increase of storey thickness from 5 inch to 10 inch and from 10 inch to 20 inch it is decreased. This trend is found from zone II to zone $\mathrm{V}$ which is shown in figure 8 (b).

From the figure 8 (c) shown below, it is being observed that for P3 percentage reinforcement is increased with the increase of storey thickness (from 5 inch to 10 inch) and from 10 inch to $20 \mathrm{inch}$ it is decreased. This trend is found from zone II to zone IV. In case of zone $\mathrm{V}$ a linear decrement is found from 5 inch to 20 inch.

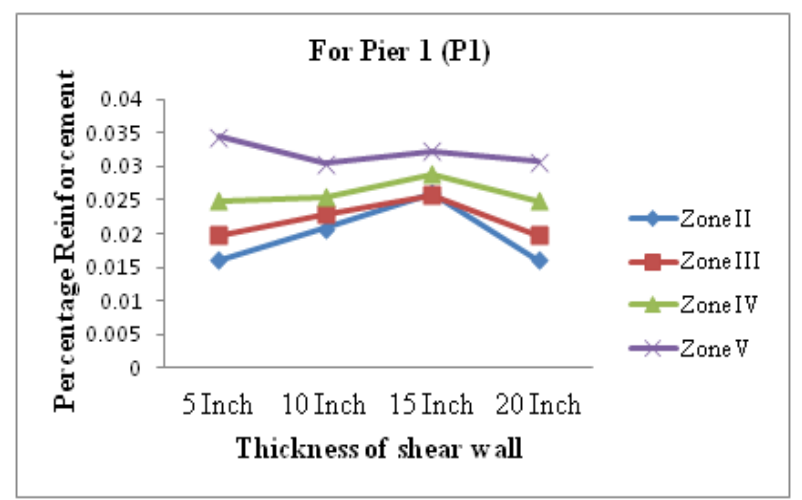

Fig-8(a): For Pier 1

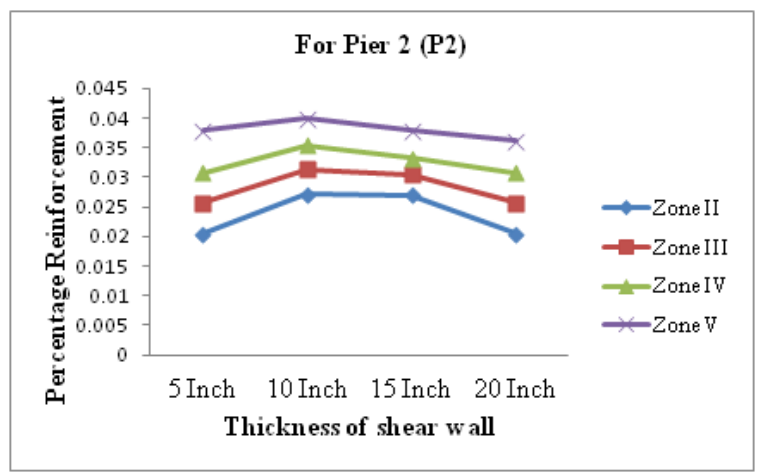

Fig-8(b): For Pier 2

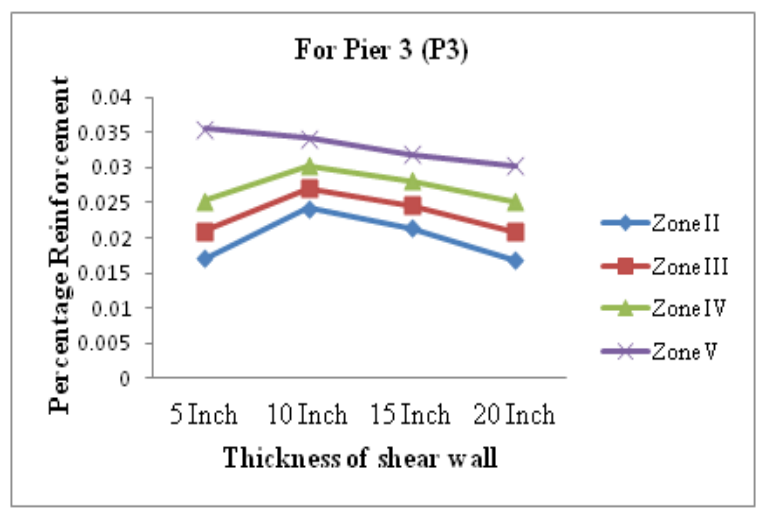

Fig-8(c): For Pier 3

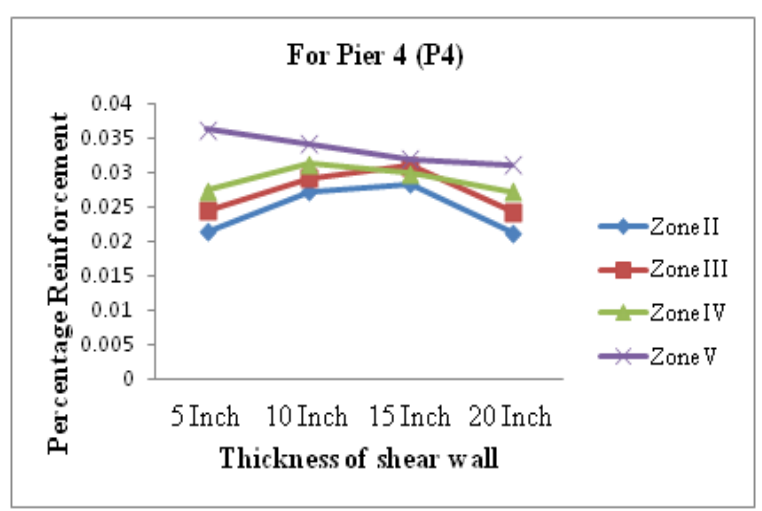

Fig-8(d): For Pier 4

Fig-8: Percentage Reinforcement against the thickness of the shear wall for different piers and seismic zone 
For $\mathrm{P} 4$ it is noticed that percentage reinforcement is increased with the increase of storey thickness from 5 inch to 15 inch and from 15 inch to 20 inch it is decreased. This trend is found from zone II to zone IV. In case of zone V a linear decrement is found from 5 inch to $20 \mathrm{inch}$, which is shown in figure $8(d)$.

\subsection{Category 4}

From the figure 9 (a) it can be predicted that for 5 inch thick shear wall percentage reinforcement is increased with the increase of storey height from 5 storey level to 10 storey level but decreased from 10 to 15 storey level.

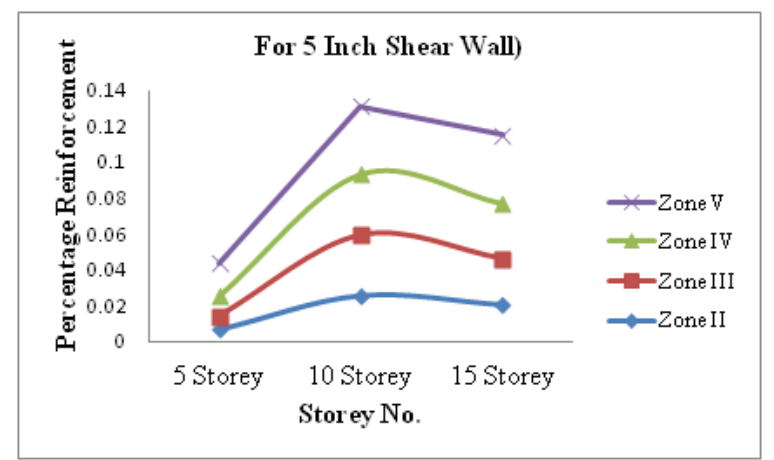

Fig-9(a): For 5 inch shear wall

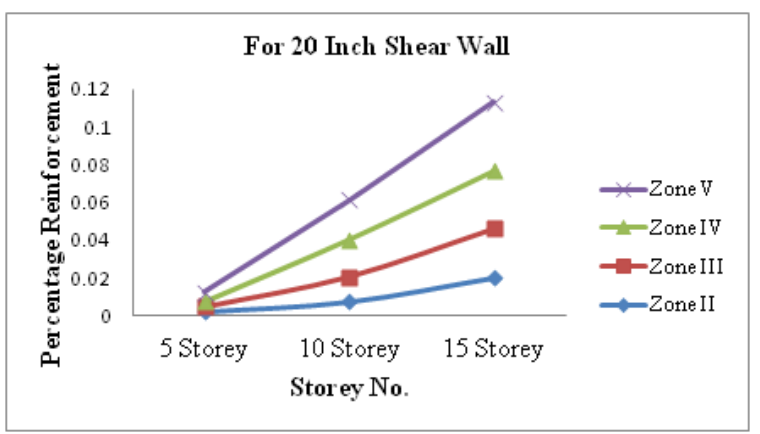

Fig-9(b): For 20 inch shear wall

Fig-9: Percentage Reinforcement against the storey height for 5 inch \& 20 inch thick shear wall for different seismic zones

In case of 20 inch shear wall percentage reinforcement is linearly increased with the increase of storey height and seismic zone which is shown in figure 9 (b).

\subsection{Category 5}

From the figure 10 (a) it is found that for 20 inch thick shear wall in case of $\mathrm{P} 2$ percentage reinforcement is maximum for zone $\mathrm{V}$ of 5 storey building, in other case it is similar through zone II to zone V.

From the figure 10 (b) it is found that for 20 inch thick shear wall in case of $\mathrm{P} 4$ percentage reinforcement is maximum for zone $\mathrm{V}$ of 10 storey building, in other case $\mathrm{P} 2$ percentage reinforcement is maximum for zone II to zone IV.
From the figure $10(\mathrm{c})$ it is found that for 20 inch thickness of the shear wall $\mathrm{P} 2$, percentage reinforcement is maximum for every zone of 15 storey building.

\section{CONCLUSIONS}

From the results obtained, followings can be concluded:

For a constant thickness of the shear wall, the reinforcement percentage of shear walls at

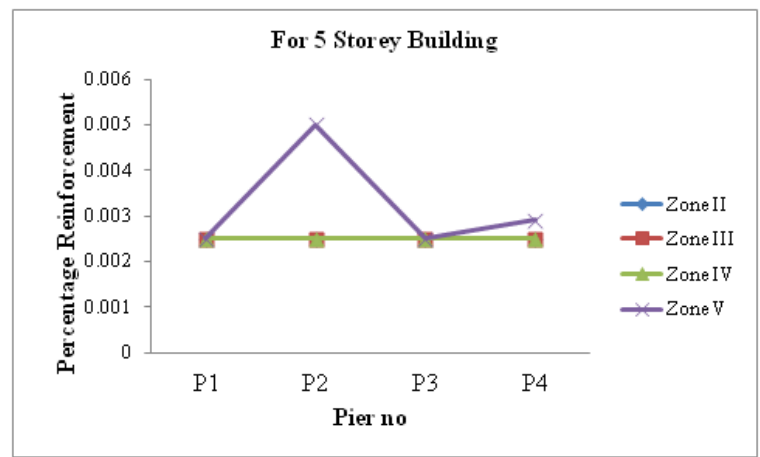

Fig-10(a): For 5 storey building

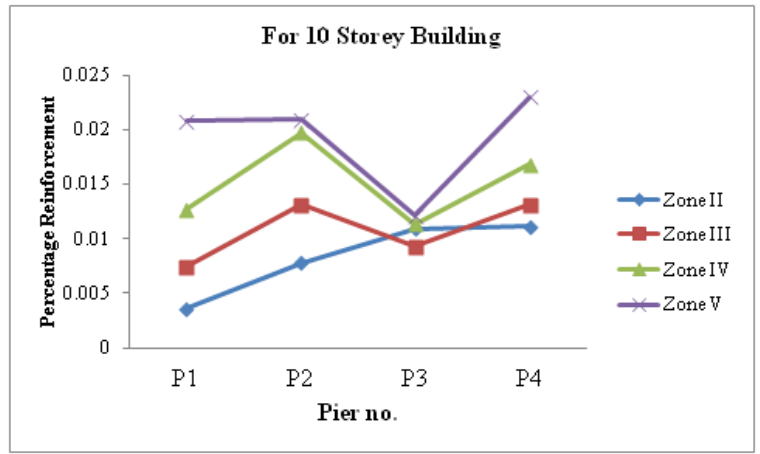

Fig-10(b): For 10 storey building

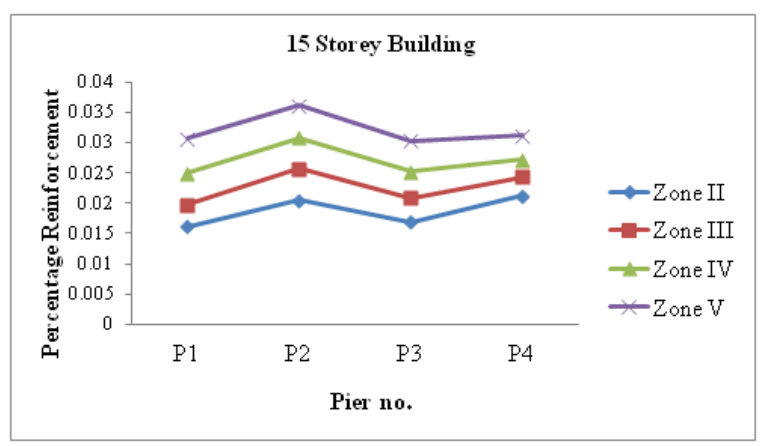

Fig-10(c): For 15 storey building

Fig-10: Percentage Reinforcement against the pier number for 20 inch thick shear wall for different storey level \& different seismic zone

different locations increases with the severity of seismic zone. One observation of the study is the steep increase of reinforcement percentage when the seismic zone changes from Zone-IV to Zone-V. 
It is observed that with the increase in the number of stories the reinforcement percentage of the shear wall increases from lower most severe zone to highest severity (Zone-II to Zone-V).

It can be concluded that increase of shear wall thickness is not always beneficial for earthquake resistance design. This is primarily due to the pattern of response spectra curve as provided in IS: 1893-2002. If the natural time period of the building becomes such that it falls in a zone of the response spectra curve where there is a reduced acceleration, then the base shear reduces \& hence the storey shear also get reduced. If the storey shear gets reduced then the reinforcement percentage also gets reduced.

From overall observation it is found that shear wall thickness of 5 inch for 5 storey, 10 storey and 15 storey level provides proper seismic safety with minimum amount of reinforcement (in case of Zone-II to Zone-IV). Shear wall thickness of 20 inch provides proper seismic safety. However in most cases it is found that the reinforcement percentage is more in case of 20 inch thick shear wall than the wall with thickness of 5 inch.

Hence, it can be concluded that 5 inch shear wall thickness will be sufficient in case of the low rise to medium rise building, which will provide lot of cost benefit. In case of Zone-V only 10 inch thickness is found to be most safe and economical thickness.

\section{REFERENCES}

[1]. Balkaya C. and Kalkan E. 'Estimation of fundamental periods of shear-wall dominant building structures', Earthquake Engineering and Structural. Dynamics. 2003; 32:985-998.

[2]. Balkaya C, Schnobrich WC. 'Nonlinear 3-D behavior of shear-wall dominant RC building structures', Structural Engineering and Mechanics 1993; 1:1-16.

[3]. Computers And Structures, Inc., ETABS Non-Linear Version 9.5.0, Berkeley, California

[4]. O. Esmaili et al. 'Study of Structural RC Shear Wall System in a 56-Story RC Tall Building', The 14th World Conference on Earthquake Engineering October 12-17, 2008, Beijing, China.

[5]. Agarwal P. and Shrikhande M. 'Earthquake Resistance Design of Structures', PHI Learning Private Ltd. New Delhi 2008.

[6]. Duggal S.K. 'Earthquake Resistance Design of Structures', Oxford University Press, New Delhi, 2007.

\section{BIOGRAPHY}

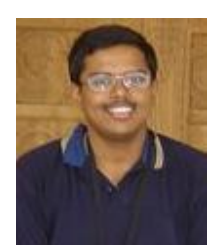

The author has done his M.Tech in Structural Dynamics from IIT, Roorkee in 2001. Post that he has worked for Tata Consultancy Services Ltd for ten years. From 2011 the author has started his career as a faculty member of Civil Engineering and presently pursuing his Phd at NIT, Durgapur as parttime research scholar. 